\title{
Development of the Double Layer Rubric for the Study on the Implementation of School-based Assessment Among Teachers
}

\author{
Mohd Sahandri Gani Bin Hamzah, Noorzeliana Idris \\ Sultan Idris Education University, Tanjong Malim, Malaysia \\ Saifuddin Kumar Abdullah \\ Ministry of Education, Putrajaya, Malaysia \\ Norazilawati Abdullah, Mazura Mastura Muhammad \\ Sultan Idris Education University, Tanjong Malim, Malaysia
}

\begin{abstract}
The school-based assessment (SBA) is a holistic assessment which evaluates the cognitive, affective, and psychomotor aspects in line with the goals of the Malaysian National Philosophy of Education (NPE) in the national curriculum. The extent of achieving the goals of the NPE and national education depends on the teachers as its implementers. Therefore, this study aims to identify the extent of the implementation of SBA within teachers from the aspect of knowledge and skills, teachers' planning, the implementation of assessment, item construction, as well as teachers' restraints in implementing SBA. Through the literature analyses related to the implementation of SBA, it was found that many teachers did not know and were not skilled in assessing their students. This could affect the reliability and the validity of the assessment. In the many studies that were observed, a majority of teachers still refuse to accept the implementation of SBA. A detailed response is needed to gain the correct information from the teachers. The use of rubrics in the instruments enables gaining more detailed information and reports which are more profound could be presented. This study discusses the steps in constructing instruments in the form of the double layer rubric to identify the extent of SBA implementation within teachers. The Instrument Determination Table was developed to accommodate related elements until it produces items which are able to measure a construct or sub-construct. After the validation process from five professionals, a pilot study was conducted. The discussion focuses on the issues and the procedures on the methods in which the validity and reliability of the instruments were built on through five professionals and the internal uniformity via the Cronbach's alpha. Therefore, the item analysis to determine the status of statements can be explained by the scores of each rubric objectively and systematically. Undeniably, the uniqueness of an instrument does not only depend on the
\end{abstract}

Mohd Sahandri Gani Bin Hamzah, B.S., M.Ed., PhD., professor, Faculty of Education and Human Development, Sultan Idris Education University.

Noorzeliana Idris, B.Ed., M.A., Ph.D. candidate, Faculty of Education and Human Development, Sultan Idris Education University.

Saifuddin Kumar Abdullah, B.Ed., M.Ed., Ph.D. candidate, Department of Polytechnic, Ministry of Education.

Norazilawati Abdullah, B.Ed., M.Ed., Ph.D., lecturer, Faculty of Education and Human Development, Sultan Idris Education University.

Mazura Mastura Muhammad, B.Ed., M.A., Ph.D., lecturer, Faculty of Languages and Communication, Sultan Idris Education University. 
issues of validity and reliability, but also on the creativity of researchers as well as the method in which these evidences can be integrated in the context of research design. What is certain here is that the uniqueness of an instrument will be further highlighted if the study is able to produce findings that can bring impact towards the progress of education. It is hoped that this rubric can be used more effectively in measuring what is needed to be measured in the SBA implementation study within teachers.

Keywords: school-based assessment (SBA), double layer rubric, Instrument Determination Table

\section{Introduction}

According to the aims of the Malaysian National Philosophy of Education (NPE), the intended outcome of the philosophy is an individual who is complete and equipped, not the one who just passes examimations. Generally, it can be observed that Malaysian educational system encourages students to learn and memorise for the sake of examination. Knowledge received in this way will not last and students may forget what they have learnt right after the examinations. This means that success in examinations cannot provide a real illustration on the success of mastering a curriculum (Omar, 2001; Azman, 1987).

The Malaysian Ministry of Education (MoE) is very concerned towards the claims that the national education system has become too exam-oriented (MoE, 2012). Therefore, a cabinet meeting dated 17th December, 2010, has agreed to the implementation of SBA as a part of the education transformation programme. It concurs with the vision and aspiration stated in the early report of the Malaysian Educational Development Plan 2013-2025, where the MoE had stressed on the concept of quality that is compulsory within each student. The school-based assessment (SBA) is an assessment that is holistic and is able to assess the cognitive (intellectual), affective (emotional and spiritual), and psychomotor (physical) aspects in accordance with the NPE, the Primary School Standard Curriculum, and the Secondary School Standard Curriculum. Nevertheless, the effectiveness of a reform in education relies on the factor of teachers who carry out the assessment. Change will not exist if the teachers do not understand the need to change and ready to change the paradigm. It is hoped that this form of assessment will produce human capital that are critical, creative, innovative, competitive, and progressive as hoped by the nation (Malaysian Examinations Syndicate, 2012).

Based on this study, the construction of the research instruments is done using the double layer rubric scale. This approach is able to provide a more detailed input which does not only cover the score scale status, but also explains the levels according to the rubric scores. The strengths of using this instrument for each item or statement do not lie only on the focus of the score mean status, but on the ability to further determine the level of weak, medium, or strong with clearer descriptive explanation. The findings would also be simpler to read on the report, facilitate solution finding, and note recommendations more quickly and meaningfully.

\section{Problem Statement}

The observation and talk of teachers in schools lead to a realisation that teachers are feeling very worried about the burden of tasks, like the burden of planning and designing as well as implementing assessment on their students. This statement has been discussed in the findings of Tunstall's (2001) study on teachers' worries related to SBA in assessment. This situation explains that assessing students can be difficult, especially for new teachers who have just started their service in a school. 
It is generally known that SBA is a new epoch in the assessment system by the MoE of Malaysia that will abolish central examinations, such as the Primary School Achievement Test (UPSR) and Lower Secondary Assessment (PMR). Hence, teachers are given full responsibility in assessing their students according to the standard assessment procedure on the students. Even though teachers have undergone courses organised by the MoE, they still lack the confidence in assessing students. This situation is further exacerbated when teachers have inadequate knowledge, skills, and materials to assist them in the assessment. This situation was brought forth by Radin (2008), who said that teachers wish for a more professional training in assessment to gain the knowledge and skills, so that SBA can be implemented more successfully. Teachers want to be equipped with resources, such as the Performance Standards document, assessment manual, instrument examples, marking schemes, and many more. Training and workshops are very important to increase the skills and confidence of teachers to design the form and the implementation of SBA.

Overall, SBA plays a role in testing and evaluating the performance of students in all aspects, but there is also limitation in terms of accuracy because the total number of students in classroom is still exceed than 40 . The assessment covers academic, co-curricular, and character performance throughout students' experiences in the teaching and learning process. Teachers who are given responsibility and play roles in carrying out SBA in rigorous and systematic process need to follow all the necessary steps and procedures of assessment. However, the lack of seriousness of the teachers in assessing will disrupt the whole assessment system. The quality of assessment can be questioned by all if there is no monitoring system. If this happens, it could lead to unfairness, non-transparency, and disuniformity in assessing students, even though fairness, transparency, and uniformity are important elements in determining correct grades are given to students throughout their learning process. This situation was discussed by Tan (2010), who highlights on the lack of monitoring system which will lead to frivolousness of the teachers in assessing their students. Therefore, teachers need to be monitored using a valid and suitable assessment standard.

The exam system has given emotional pressure to parents, teachers, and even the students themselves. However, the exam system has actually restrained students' creativity to present and show their performance as well as their real abilities in learning. Teachers have also become less creative in their learning patterns when they teach for exams. All this time, teachers are the ones who work hard in carrying out the teaching and learning process, but external examiners are the ones who assess their students. SBA will return the right of assessment to the teachers and teachers would have to change their teaching patterns by using many teaching strategies, so that students would fully master learning. However, from the observation, teachers consider that the varying teaching strategies would only waste time because assessments need to be done after teaching. While teaching, teacher can access, and at the same time, they have to guide and report their performance instantaneously. This view was denied by Tseko (2005), who mentioned that SBA is very important for students, because assessment is conducted in the teaching and learning process, hence, allowing the students to know their ability and performance. In other words, while teaching, teachers can access, and at the same time, guide and report on their students' performance instantaneously.

Nonetheless, after almost four years of implementing SBA in schools, teachers have started to complain about the amount of burden that has to be shouldered and this has reached even the news. Many teachers agree on the abolishment of SBA. This is further supported by an online study by the MoE to see the agreement of teachers in implementing SBA, where almost $75 \%$ of the teachers agree on its discontinuation. This was further proven by the support (more than 70,000 teachers) given on Facebook page created especially for the 
abolishment of SBA (https://www.facebook.com/KamiMahuSPPBSDimansuhkan). Furthermore, the MoE has stopped the implementation temporarily in February, 2013, to re-study all the complaints being made on the implementation of SBA, which was said to be in haste. The burdens of teachers were also discussed in a study by Tan (2010). Among the burdens discussed are clerical work, marks input process, and the filing system that limits teachers' creativity in implementing SBA. Because SBA has been implemented in Malaysia since 2010, a comprehensive study needs to be conducted to evaluate the procedures, planning and executing processes, as well as the teachers' restraints in the implemention.

\section{The Implementation of SBA}

Current assessments are based on the curriculum that only covers the ability of students in remembering and memorising. Other skills are not applied, analysed, synthesised, and evaluated in an evaluation (Begum \& Farooqui, 2008). SBA was initially used as a new method in the educational system because of the increasing awareness on the tests that are only based on the curriculum and teaching (Dikli, 2003).

The type of assessment also provides focus towards the development and performance of teachers where if a student fails to complete the task given at certain times, the student still has the chance to show his/her skills on other different times and situations. Since SBA was developed in the contexts from one time to another, teachers have the chance to measure the strengths and weaknesses of stuents in many fields and situations (Law \& Eckes, 1995). Hence, teachers need to have adequate knowledge and skills before conducting assessment. Consistent with Shapard (2000), teachers who make changes need to be given the knowledge and skills:

... Progressive educational required infinitely skilled teacher being able to ask the right questions at the right time, anticipate conceptual pitfalls, and have at the read repertoire of task that will help student take the next step requires deep knowledge of subject matter. Teachers will also need knowledge in learning to use assessment in a new way. (Shapard, 2000, p. 71)

Arranged planning before assessment is needed for teachers to ensure the fluidity of the assessment process. James and Charles (1995) stated in their book, Management, that planning is defined as a guideline designed to achieve the initial meaning of the founding. Meanwhile, planning helps the management of the organisation to determine the direction of the organisation, and decide on issues related to the questions on what, when, and how a plan is going to be executed and who will carry out the execution.

Namara (1998) added and explained that effective programme planning needs to be prepared consistent with the missions and goals of the organisation through teamwork and structure while determining the keys to success, recheck, and evaluate the planning for the programme. The opinion of Namara (1998) is consistent with the opinion of the the Malaysian Examinations Syndicate (2013), who stated that detail planning needs to be executed in groups between the Malaysian Examination Syndicate, state educational departments, and appointed SBA executors. Therefore, in schools, all teachers' planning needs to be robust before teaching, so that assessments can be applied successfully.

Stoner and Wankel (1995) have given the view that "planning without executing is a wasted act". After planning, execution is needed. Seeing that assessment and instrument construction is a compulsory matter for all teachers in executing SBA (Malaysian Examination Syndicate, 2012), teachers will need to plan first, so that their execution is more orderly and systematic. However, it is believed that there are many restraints for teachers throughout the implementation of SBA. 
In the context of this study, SBA teachers will provide response on their knowledge and skills, planning and execution of assessment, and instrument construction, as well as the restraints faced by them throughout the implementation of SBA.

\section{The Development of Constructing a Double Layer Rubric Instrument}

The analysis instrument for the implementation of SBA within teachers is based on previous literature and studies. There are 28 items and 133 rubrics which are then categorised into five constructs consisting of:

(a) Teachers' knowledge and skills;

(b) Teachers' planning in executing the SBA;

(c) Execution of the SBA;

(d) SBA instrument construction;

(e) Teachers' restraints in executing SBA.

In this study, the construction of the double layer instrument went through six levels. Firlty, the constructs of SBA implementation by teachers are checked through literature analysis and documents from the MoE. Secondly, to identify the accuracy of the constructs of SBA implementation within teachers, a structured interview was planned. Two officers from the District Education Office and a school main trainer were interviewed to update the items and rubrics constructed. The third step involved checks by five professionals in the field of curriculum on the items and rubrics to as well as suggestions for improvement. The fourth step involved rechecking of the items based on the comments and inputs gained from the group of professionals. The fifth step involved the construction of the Instrument Determination Table consisting of planning and complete set determination by considering the rubric scales and scores. Constructs and sub-constructs which were determined were supported by literature whereas trait and item designs based on the subjects and predicates were controlled by syllabus and the principles of measuring and assessment (see Table 1). The final step in item construction involved item testing through pilot study to observe the readability, clarity, and accuracy of the items. By doing these, the instructions and statements for any items that are not clear can be identified and then changed.

The final version of the instrument was successfully produced containing 28 items with 133 rubrics, and each item contains five rubrics that represent certain evaluation scales, as shown in Table 2.

Table 1

Test Determination Table

\begin{tabular}{|c|c|c|c|}
\hline Construct & Sub-construct & & Scale \\
\hline & $\begin{array}{l}\text { B1a. Teachers' } \\
\text { knowledge and skills } \\
\text { resources }\end{array}$ & 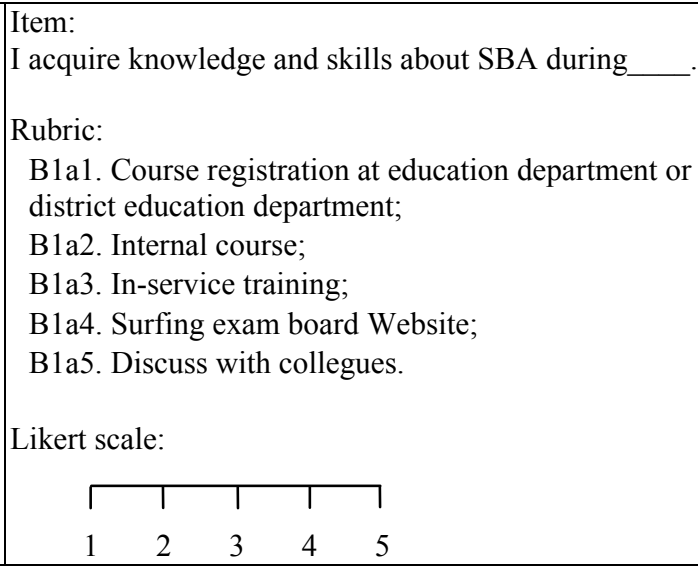 & $\begin{array}{l}0-\text { No; } \\
1-\text { Yes. }\end{array}$ \\
\hline
\end{tabular}


(Table 1 to be continued)

\begin{tabular}{|c|c|c|c|}
\hline \multirow{3}{*}{$\begin{array}{l}\text { B1. Knowledge and } \\
\text { skills }\end{array}$} & $\begin{array}{l}\text { B1b. Teacher's } \\
\text { knowledge in } \\
\text { implementing SBA }\end{array}$ & $\begin{array}{l}\text { Item: } \\
\text { I know how to do the following activities: } \\
\text { Rubric: } \\
\text { B1b1. Develop instruments; } \\
\text { B1b2. Use instruments for assessing students; } \\
\text { B1b3. Assess the evidence of students; } \\
\text { B1b4. Explainthe assessment criteria to the students; } \\
\text { B1b5. Adjust the instrument with the teaching method. } \\
\text { Likert scale: } \\
\qquad \begin{array}{l|l|l|}1 & 3\end{array}\end{array}$ & $\begin{array}{l}\text { 0-Do not know; } \\
\text { 1-Know some; } \\
\text { 2-Fully know. }\end{array}$ \\
\hline & $\begin{array}{l}\text { B1c. Teachers' skills in } \\
\text { implementing SBA }\end{array}$ & $\begin{array}{l}\text { Item: } \\
\text { I am skilled to do the following: } \\
\text { Rubric: } \\
\text { B1c1. Develop instruments; } \\
\text { B1c2. Use instruments for assessing students; } \\
\text { B1c3. Assess the evidence of students; } \\
\text { B1c4. Explain the assessment criteria to the } \\
\text { students; } \\
\text { B1c5. Adjust the instrument with the teaching } \\
\text { method. } \\
\text { Likert scale: } \\
\qquad 1 \\
1\end{array}$ & $\begin{array}{l}0 \text {-Unskilled; } \\
1 \text {-Skilled at } \\
\text { certain part; } \\
2-\text { Fully skilled. }\end{array}$ \\
\hline & $\begin{array}{l}\text { B1d. Teachers' } \\
\text { knowledge about the } \\
\text { terms in SBA }\end{array}$ & $\begin{array}{l}\text { Item: } \\
\text { I understand the term of following assessment: } \\
\text { Rubric: } \\
\text { B1d1. Document Standard Performance; } \\
\text { B1d2. Document Standard Curriculum; } \\
\text { B1d3. Descriptor; } \\
\text { B1d4. Bands; } \\
\text { B1d5. Malaysian Educational Development Plan. } \\
\text { Likert scale: } \\
\qquad \begin{array}{r|r|r|} & & \\
1 & 2 & 4\end{array} \\
\end{array}$ & $\begin{array}{l}0 \text {-Do not } \\
\text { understand; } \\
\text { 1-Understand } \\
\text { certain part; } \\
\text { 2-Fully } \\
\text { understand. }\end{array}$ \\
\hline $\begin{array}{l}\text { B2. Teachers' } \\
\text { planning }\end{array}$ & $\begin{array}{l}\text { B2a. Teachers' planning } \\
\text { B2b. Planning before SB } \\
\text { B2c. Instrument construc } \\
\text { B2d. Planning before tea }\end{array}$ & $\begin{array}{l}\text { status; } \\
\text { A assessment; } \\
\text { ction planning; } \\
\text { ching. }\end{array}$ & $\begin{array}{l}0 \text {-No; } \\
1 \text {-Sometimes; } \\
2 \text {-Yes. }\end{array}$ \\
\hline $\begin{array}{l}\text { B3. Implementaion of } \\
\text { the SBA assessment }\end{array}$ & $\begin{array}{l}\text { B3a. Teachers' status in } \\
\text { B3b. Things done throug } \\
\text { B3c. Teachers' practice } \\
\text { B3d. Things done by tea } \\
\text { B3e. Things done during } \\
\text { B3f. Things done in the } 1 \\
\text { B3g. Method teachers us } \\
\text { B3h. Ways teachers conc } \\
\text { B3i. Criteria during stud } \\
\text { B3j. Teachers' assessme } \\
\text { B3k. Teachers reporting }\end{array}$ & $\begin{array}{l}\text { implementing SBA; } \\
\text { shout the assessment activities; } \\
\text { in assessment; } \\
\text { chers for students who have not master the learning; } \\
\text { assessment; } \\
\text { process of assessment; } \\
\text { do manage students' evidence; } \\
\text { duct scoring; } \\
\text { ents assessment; } \\
\text { nt criteria; } \\
\text { criteria. }\end{array}$ & $\begin{array}{l}0 \text {-No; } \\
1 \text {-Sometimes; } \\
2 \text {-Yes. }\end{array}$ \\
\hline
\end{tabular}


(Table 1 to be continued)

\begin{tabular}{|c|c|c|}
\hline $\begin{array}{l}\text { B4. Instrument } \\
\text { construction }\end{array}$ & $\begin{array}{l}\text { B4a. Teachers' status in instrument construction; } \\
\text { B4b. Ways teachers prepare instruments; } \\
\text { B4c. Ways teachers construct instruments; } \\
\text { B4d. Instruments used by teachers; } \\
\text { B4e. Other instruments used by teachers. }\end{array}$ & $\begin{array}{l}0 \text {-No; } \\
1 \text {-Sometimes; } \\
2 \text {-Yes. }\end{array}$ \\
\hline $\begin{array}{l}\text { B5. Teachers' } \\
\text { restraints in } \\
\text { implementing SBA }\end{array}$ & $\begin{array}{l}\text { B5a. Teachers' problems in implementing SBA; } \\
\text { B5b. Types of problems faced by teachers; } \\
\text { B5c. Teachers' problems during implementing SBA; } \\
\text { B5d. Teachers' burden throughout implementing SBA. }\end{array}$ & $\begin{array}{l}0 \text {-No; } \\
1 \text {-Sometimes; } \\
2 \text {-Yes. }\end{array}$ \\
\hline
\end{tabular}

Table 2

\section{Rubric Score}

\begin{tabular}{lllllll}
\hline Statements & \multicolumn{1}{l}{} & & & Rubric score \\
\hline Do not know & Not skilled & Disagree & No & No & No & 0 \\
Partially know & Partially skilled & Agree & Sometimes & Some parts & Yes & 1 \\
Completely know & Completely skilled & Strongly agree & Yes & Yes & Yes & 2 \\
\hline No & - & - & - & - & - & 0 \\
Yes & - & - & - & - & - & 1 \\
\hline Total rubric (5) & 1 & 2 & 3 & 4 & 5 & - \\
Total rubric (10) & $0-2$ & $3-4$ & $5-6$ & $7-8$ & $9-10$ & - \\
Likert scale & 1 & 2 & 3 & 4 & 5 & - \\
\hline
\end{tabular}

The 5-point scale is counted by researchers resulting from respondents' evaluation based on five rubrics. Each rubric brings a score ranging from 0 to 2 ( 0 = "No"; 1 = "Sometimes"; and 2 = "Yes"). The total rubric scores are 10 points. These scores will be transferred to the ordinal scale, as shown in Table 3 .

Table 3

Respondents' Evaluation Based on Five Rubrics

\begin{tabular}{ll}
\hline Rubric score & Ordinal scale \\
\hline $0-2$ & 1 \\
$3-4$ & 2 \\
$5-6$ & 3 \\
$7-8$ & 4 \\
$9-10$ & 5 \\
\hline
\end{tabular}

For the dichotomy scales, the total rubric scores are 5 points. These scores will be transferred to the ordinal scales, as shown in Table 4.

Table 4

Measurement Scale

\begin{tabular}{ll}
\hline Rubric score & Ordinal scale \\
\hline $0-1$ & 1 \\
2 & 2 \\
3 & 3 \\
4 & 4 \\
5 & 5 \\
\hline
\end{tabular}

\section{Instrument Validation}

The instrument is validated for each item by five professionals who determine the suitability of the evaluated construct. One of the principles used in ensuring validation of the instrument is by making certain 
that each item is agreed by the five professionals. The minimum percentage of agreement for each item validated should not be less than $80 \%$.

\section{Pilot Study}

A pilot study was conducted first to ensure that the reliability of instrument record an index of no less than 0.67 (Nunnally, 1982) for the newly constructed instruments. It is also to ensure the accuracy of the instrument. The pilot study was carried out on 57 people consisting of primary and secondary school teachers. The pilot study instrument was conducted via the interaction survey method. The teachers are grouped into two groups and the researchers read and explain each item to ensure that all respondents have the same understanding of the items. Nonetheless, the response for each item is not guided by the researchers.

\section{Reliability}

The validity of a test relies on the reliability of that test. Because of that, only the measuring tool that can give consistent readings can help the tool to give a valid measurement. Reliability is related to the level of consistency between two measurements for the same reason (Creswell, 2003). Reliability is also the level that shows that the measurement is free from error and can then produce consistent results. Reliability refers to internal stability and consistency of the instrument in measuring a concept (Creswell, 2003).

A popular and frequently used test in measuring the internal consistency of a concept is the Cronbach's alpha method (Cronbach, 1949; Norusis, 2005). The alpha coefficient value near to 1.00 shows that the items in the scale are measuring the same things and have high reliability. According to Mohd (2005), a minimum value of 0.6 is needed as a reliability index for the instruments to be used. Any value lower than that indicates that the items are unacceptable. Alpha values of 0.6-0.8 are deemed acceptable and values more than 0.8 are deemed good and have high reliability.

In this study, data analysis is conducted using the Statistic Package of Social Science (SPSS) Version 19 programme. The results of the reliability of the items processed are shown in Table 5.

Table 5

Cronbach's Alpha Coefficient

\begin{tabular}{lcll}
\hline Input apects & Total items & Item correlation and total scores & Cronbach's alpha value \\
\hline Knowledge and skills & 4 & 0.776 & 0.887 \\
Teachers' planning & 4 & 0.526 & 0.863 \\
SBA construction execution & 11 & 0.762 & 0.886 \\
Instrument construction execution & 5 & 0.667 & 0.887 \\
Teachers' restraints in executing SBA & 4 & 0.564 & 0.885 \\
\hline
\end{tabular}

\section{Results}

Table 5 summarises the reliability coefficients obtained from all the constructs of SBA implementation within teachers. Based on Table 5, it was found that the Cronbach's alpha value is in the range of 0.863-0.887; it was also found that the number of items for each component does not give the same effects towards the reliability index given, which is the dimension of SBA assessment implementation $(N=11)$, even though there are more items compared to the dimensions regarding teachers' restraints in implementing SBA $(N=4)$, but produce almost similar alpha values. From the alpha value obtained, and through considering the segregation of the respondents based on two stratas (primary and secondary schools) that exist, it can be concluded that the 
score variation obtained is high. In short, the reliability index values obtained were quite high because of the variety of several responses of SBA implementation within teachers that functions on the involved strata in featuring the respondents.

\section{Item Analysis}

Based on the SPSS analysis instruction in the descriptive part by following the steps and procedures that started from the click on the analysis icon, and then select descriptive statistic and related items, the results are shown in Table 6.

Based on Table 6, the numbers show the mean scores and standard deviations for the items of knowledge and skills $(M=3.81 ; S D=0.26)$, teachers' planning $(M=4.15 ; S D=0.53)$, SBA assessment execution $(M=$ 3.16; $S D=0.67)$, instrument construction $(M=3.52 ; S D=0.55)$, and teachers' restraints in implementing SBA $(M=3.72 ; S D=0.75)$ from the 57 respondents processed. The interpretation towards the items shows that the respondents have knowledge and skills as well as planning at a high level compared to implementation of SBA assessment execution and instrument construction at an average level. The respondents also admitted that they have high restraints in implementing SBA. This interpretation is referred towards the standard criteria shown in Table 6 .

Table 6

Mean Scores of Items and Classification Status

\begin{tabular}{lllll}
\hline & $N$ & $M$ & $S D$ & Status \\
\hline Knowledge and skill & 57 & 3.81 & 0.26 & High \\
Teacher's planning & 57 & 4.15 & 0.53 & High \\
SBA assessment execution & 57 & 3.16 & 0.67 & Average \\
Instrument construction & 57 & 3.52 & 0.55 & Average \\
Teachers' restraints & 57 & 3.72 & 0.75 & High \\
\hline
\end{tabular}

The researcher has produced an implementation to classify the mean value of high, moderate, and low. All three categories are shown in Table 7.

Table 7

Three Cateogies of Mean Score Interpretation

\begin{tabular}{ll}
\hline Score & Interpretation \\
\hline $1.00-2.33$ & Low level \\
$2.34-3.66$ & Moderate level \\
$3.67-5.00$ & High level \\
\hline
\end{tabular}

Note. Source: Mohd Sahandri (2011).

\section{Item Descriptive Analysis}

An analysis on a few descriptive items according to the rubric used in summarising the mean scores as well as strengths and weaknesses is shown in Table 8 .

The statistics in the Table 8 show descriptive score for the implementation of SBA among teachers in two constructs: (a) skills and knowledge of teachers; and (b) instrument construction.

For the construct skills and knowledge, the mean score (3.81) is at a high level. Item 1 of this construct is knowledge resource and teachers' skills, which shows that $91 \%$ of the teachers get their knowledge and skills 
from internal courses while $44 \%$ of them through the examination syndicate Website. However, for item 2, teacher's knowledge in implementing SBA, it shows that $93 \%$ of the teachers use the Performance Standards document and only $16 \%$ of the teachers do not know how to assess the students.

In the construct of instrument construction, the mean score (3.52) is at a moderate level. For item 1 of this construct, the ways of teachers in constructing the instruments show that $63 \%$ of the teachers know a part of constructing an instrument and only $14 \%$ of them do not know how to construct their instruments. In item 2 , instruments used by teachers, $89 \%$ of the teachers use pencil and paper as assessment instruments and only $3 \%$ of them use projects as assessment instruments.

Table 8

Item Descriptives

\begin{tabular}{|c|c|c|c|}
\hline Construct/variable & Mean score & Item & Elaboration \\
\hline \multirow[t]{3}{*}{ Skills and knowledge } & \multirow{3}{*}{$\begin{array}{l}3.81 \\
\text { High }\end{array}$} & $\begin{array}{l}\text { Knowledge resourse and } \\
\text { teachers' skills }\end{array}$ & $\begin{array}{l}91 \% \text { of the teachers get their knowledge and skills from internal } \\
\text { courses } \\
44 \% \text { of the teachers get the knowledge and skills by surfing the } \\
\text { Examination Syndicate Website } \\
\end{array}$ \\
\hline & & \multirow{2}{*}{$\begin{array}{l}\text { Teacher's knowledge in } \\
\text { implementing SBA }\end{array}$} & $93 \%$ of the teachers use the Performance Standards document \\
\hline & & & $16 \%$ of the teachers do not know how to assess students \\
\hline \multirow{3}{*}{ Instrument construction } & \multirow{3}{*}{$\begin{array}{l}3.52 \\
\text { Moderate }\end{array}$} & $\begin{array}{l}\text { Ways teachers construct } \\
\text { instruments }\end{array}$ & $\begin{array}{l}\begin{array}{l}63 \% \text { of the teachers know only a part of constructing an } \\
\text { instrument }\end{array} \\
\begin{array}{l}14 \% \text { of the teachers have no idea whatsoever on constructing } \\
\text { instruments }\end{array} \\
\end{array}$ \\
\hline & & \multirow{2}{*}{$\begin{array}{l}\text { Instruments used by } \\
\text { teachers }\end{array}$} & $\begin{array}{l}89 \% \text { of the teachers use pencil and paper as assessment } \\
\text { instruments }\end{array}$ \\
\hline & & & Only $3 \%$ of the teachers use projects as assessment instruments \\
\hline
\end{tabular}

\section{The Potential of Instrument Use in SBA Implementation Within Teachers}

Even though the instruments in this study possess high reliability, follow-up refinement needs to be done to improve the items of SBA implementation in ensuring an effective instrument is used in this study. The discussion focused on determining the validity and reliability of the instrument by gaining assistance from five professionals and internal consistency of Cronbach's alpha. Both these techniques are stable and consistent alternatives in justifying the validity and reliability of the items produced. As stated, a few series of items refinement need to be done through a few series of replication studies, especially in involving more respondents.

The use of double layer rubric instrument produced for this study can help to determine the extent of SBA implementation among teachers and it also enables the research to compare the individual strengths and weaknesses of the teachers (the respondents of the study) in implementing SBA. It cannot be denied that the uniqueness of this form of instrument does not only rely on the issues of validity and reliability as discussed, but also relies on the creativity of researchers to apply it in a study design.

By considering the procedures that were involved in the construction of items that were discussed, it is not extreme to conclude that the information that will be generated from this instrument can give valuable information, especially for the planners and policymakers for teachers in Malaysia. The potential of this instrument does not only measure based on the level of implementation, but also the impacts and results that will be obtained. It is hoped that this instrument of double layer rubrics will succeed in being produced and proven of its validity and reliability which will also be then used widely, especially to identify the effectiveness of implementing SBA within teachers. 


\section{Conclusion}

The implementation of SBA among teachers cannot be seen as trifles since it is a transformation in the education that hopes success at the end of its implementation. Therefore, an analysis on the extent of its implementation within teachers is needed, so that it could become a guideline to be improved from its implementation from time to time. A quality instrument is needed to measure the effectiveness in SBA within teachers, because the instrument for educational research is a mechanism that is able to measure what is intended. In relation to this, an analysis on the findings can explain the content information of the instrument items correctly. This means that the item status can explain and elaborate item statements.

Transformation in the construction of instrument items involved alogarithms based on the correct principles and steps. All constructs and variables are planned based on the syllabus that supports the research topic that is suggested. The Instrument Determination Table framework was developend by taking into account the constructs, variables, and questioning methods to explain the items and the rubrics. All these elements are driven and supported with relevant literature. Besides that, the process of validation and determining the reliability is determined after the pilot study is carried out. The strengths of the results from the process of constructing the items, where each construct, variable, or item is shown in mean scores, can be explained qualitatively in the form of rubrics.

\section{References}

Azman, W. C. (1987). Kaedahhayatiamali (Understanding practical methods). Kuala Lumpur: Karya Bistari.

Begum, M., \& Farooqui, S. (2008). School based assessment: Will it really change the education scenario in Bangladesh? International Education Studies, 1(2), 45-53.

Creswell, J. W. (2003). Educational reseach: Planning, conducting and evaluating quantitative and qualitative research. Upper Saddle River, N.J.: Pearson Education, Inc..

Cronbach, L. J. (1949). Essentials of psychological testing. New York, N.Y.: Harper \& Brothers.

Dikli, S. (2003). Assessment at a distance: Traditional vs. alternative assessments. The Turkish Online Journal of Educational Technology, 2(3), 13-19.

James, A. F. S., \& Charles, W. (1995). Management (6th ed.). New Delhi: Prentice Hall.

Law, B., \& Eckes, M. (1995). Assessment and ESL. Manitoba, Canada: Peguis Publishers.

Malaysian Examinations Syndicate. (2012). Panduan pengurusan pentaksiran berasaskan sekolah (Guidelines for SBA). Putrajaya: Ministry of Education.

Malaysian Examinations Syndicate. (2013). Buku informasi PBS (Information book on SBA). Putrajaya: Ministry of Education. Ministry of Education (MoE). (2012). Malaysian educational development plan 2013-2025. Putrajaya: Ministry of Education.

Mohd Sahandri, G. H. (2011). The effectiveness in embedding soft skills in poly-tech Mara colleges.

Mohd Sahandri, G. H., Noor Shah, S., Husni Zaim, K. N., \& Nur Nazurah, M. Y. (2013). Transformasi pembinaan instrument kajianterhadap pengurusan pengajaran guru (Assessments of instrument construction management transformation of teaching). Proceeding of The 4th National Seminar of Public University Dean Council, Kuala Lumpur, Malaysia.

Mohd, M. K. (2005). Kaedah penyelidikan pendidikan (Education research methods). Kuala Lumpur: Dewan Bahasa dan Pustaka.

Namara, C. M. (1998). Program evaluation: Some myth abaout program evaluation. Retrieved January 20, 2013, from $\mathrm{http} / /$ www.mapnp.org/library/evaluation/fnl.eval.htm

Norusis, M. J. (2005). SPSS 13.0 guide to data analysis. Englewood Cliffs, N.J.: Prentice Hall.

Nunnally, J. C. (1982). Psychometric theory. New York, N.Y.: McGraw-Hill Inc..

Omar, R. (2002). Masalah-masalah dalam pelaksanaan pentaksiran kerja amali (PEKA) di sekolah-sekolahmenengah di daerah Temerloh (Problems in implementing fieldwork in secondary schools in Temerloh) (M.Ed. thesis, Universiti Kebangsaan Malaysia).

Radin, M. S. Z. (2008). Penilaian program pentaksiran kerja kursus berasaskan sekolah teknologi kejuteraan SPM (Program evaluation of school-based coursework assessment) (Master's thesis, Universiti Kebangsaan Malaysia). 
Shapard, L. A. (2000). The role of classroom assessment on teaching and learning. Los Angeles, C.A.: Centre of Research Evaluation Standard and student testing (CRESS), University of California.

Stoner, J. A. F., \& Wankel, C. (1985). Management. London, U.K.: Prentice-Hall, Inc..

Tan, A. M. (2010). Pentaksiran berasaskan sekolah (PBS) di Malaysia: Kesediaan guru, isudan panduan pelaksanaan (SBA in Malaysia: Teacher readiness, issues and guideline of implementation) (Ph.D. dissertation, Universiti Kebangsaan Malaysia).

Tseko, G. N. (2005). A teacher with a vision and school assessment. Botswana: University of Botswana.

Tunstall, P. (2001). Assessment discourse and contributions of social reality in infant classroom. Journal of Education Policy, 16, 215-213.

West-Burnham, J. (2009). Rethinking educational leadership: From improvement to transformation. New York, N.Y.: Continuum International Publishing Group. 